or one of its multiples; hours, minutes, and seconds must be a thorn in the flesh of avid rationalisers; while even the SI units contain some compromises with what has been called purity.

So threatened, we ask only that the authorities decline in future to consider any proposal for changes in notation which come to them from any individual or group, however distinguished, unless the institutions which represent the clinicians of the nation shall have had a part in its making.

D R JoHN
Chairman,
A H JAMES
Hon Secretary,
Medical Staff Committee,
Hillingdon Hospital

Uxbridge, Middx

SIR,-The controversy over SI units conducted through your correspondence columns and those of the Lancet has provided light entertainment for many. Curiosity decided me to page through a few issues of the two journals of the early fifties, the time at which the metric system and the milliequivalent were introduced into clinical medicine. Your leading article of 7 February $1953,{ }^{1}$ mentioning the advantages of the metric system, was followed over the weeks by a series of strangely familiar letters. Correspondents refer to the safety and convenience of the older system (imperial and avoirdupois) and the "difficulties in making a complete change.". The dangers of "misplacing decimal points" are mentioned and there are semiserious attempts at ridicule -a dose of $1 \mathrm{drachm}$ per stone body weight is converted to " $3.55 \mathrm{ml}$ per $6.35 \mathrm{~kg}$."3 Small wonder that a French colleague found that "most of the objections expressed by your correspondents are so very childish." 4 Let us hope he has been spared the 1975 contributions.

Changes in reporting of electrolytes produced remarks on "the liberty with which certain blood components are expressed in milliequivalents." 5 The writer, fearing that "this makes for confusion and opens the door to serious dispensing errors," concluded that "for practical purposes it is surely more useful to retain $\mathrm{mg}$ per $100 \mathrm{ml}$-the form in which, I believe, most clinicians think, and of which they know the normal blood-levels."

Perhaps the most thought-provoking quotation is from your leading article. " "To follow this lead should not be too difficult for the medical profession even if, for a year or two, it entails a certain amount of extra thought. The lasting benefit would so outweigh the transient puzzling that medical men 20 years hence would look back in amazement at the reluctance of their seniors to institute the change."

I wonder, sir, would we dare to point a finger?

P R PANNALI

Department of chemical pathology,
University of the Orange Free State,

Bloemfontein, South Africa

1 British Medical fournal, 1953, 1, 320

Leak, W N, British Medical fournal, 1953, 1, 619

- Hewer, C L, British Medical Fournal, 1953, 1, 450.

- Mouchot, G, British Medical Fournal, 1953, 1, 1109

$\checkmark$ Ennis, J E, Lancet, 1953, 2, 990.

\section{Chemotherapy for breast cancer}

SIR,-Your interesting leading article "Curability of breast cancer" (21 February, p 414) refers to trials in America. Perhaps it would not be out of place to remind your readers that the pioneer work in chemotherapy for breast cancer was begun in Bradford in 1957 by $\mathrm{Dr}$ (now Professor) R L Turner and the late $M$ G Whyte Watson, and their first paper was published in the $B M \mathcal{F}$ in $1959 .^{1}$ It is no generally appreciated how much is owed to these two pioneers.

H FIDLER

Postgraduate School of Studies

in Medical and Surgical Sciences,
University of Bradford

1 Watson, G W, and Turner, R L, British Medical
fournal, 1959, 1, 1315.

Radiology and endoscopy in acute upper gastrointestinal bleeding

SIR,-I am interested in the paper by $\mathrm{Dr}$ G M Fraser and others (31 January, p 270) and the reaction to this by $\mathrm{Dr}$ K F R Schiller and his colleagues (14 February, p 393).

As a radiologist $I$ have stated my opinion elsewhere that "endoscopy undertaken by an experienced endoscopist takes pride of place in the investigation of the acute upper tract bleed." However, it is important to realise that emergency endoscopic services are no available to all and to take note of the remarks on this subject expressed by Forrest et al. ${ }^{2} \mathrm{At}$ the same time we should also remember that the patient suffering an acute bleed is admitted to the nearest acute hospital, whether emergency endoscopy is or is not available within 12-24 hours of the time of admission. Obvi ously radiology, as an alternative to endoscopy, has a part to play in this emergency service and, like endoscopy, must be undertaken early if we are to expect a high diagnostic yield.

The criticism by endoscopists that radiology may show a lesion but cannot demonstrate that this lesion is the source of bleeding is no longer valid. Double-contrast studies are capable of showing specific features characteristic of bleeding point which are never reproduced in any other situation. ${ }^{3}$ This additional information greatly enhances the value of emergency radiology.

It is interesting that Dr Schiller and his colleagues should refer to "this most recent attack on endoscopy, written by radiologists in defence of radiology." I recall numerous papers written by endoscopists in favour of endoscopy and questioning the role of radiology in the investigation of the acute bleed. Constructive co-operation and not empire-sustaining sharpshooting from either side would serve the best interest of the patient and give most help to the clinician responsible for the management of the case. Surely there is a happy medium based on an understanding of the needs and merits of the individual case and the facilities available at the time of admission. I agree with Mr F P McGinn and his colleagues (14 February, p 394) that "the two methods of investigation are complementary, but if a choice must lie between them then endoscopy should take precedence."

\section{W G SCOTT-HARDEN}

Department of Radiology,

Cumberland Infirmary,

Scott-Harden, W G, in Topics of Gastroenterology, 3, ed S C Truelove and

Forrest, J A H, Finlayson, N D C, and Shearman, D J C, Lancet, 1974, 2, 394. D J C, Lancet, 1974, 2, 394.
Scott-Harden, W G, fournal of the Royal College of
Physicians of London, 1974, 8, 365.
Immunisation against whooping cough

SIR,-In writing to you to defend the papers by $\mathrm{Dr}$ Christine $\mathrm{L}$ Miller and $\mathrm{Mr}$ W $\mathrm{B}$ Fletcher (17 January, $p$ 117) and by Dr N D Noah (p 128) Dr T M Pollock (14 February, p 396) dons a capacious mantle. He says that essential data were withheld from Dr Noah's paper "for the sake of brevity" - a matter which I should have thought concerned you, Sir, and Dr Noah. And he rebukes me for adhering to a basic tenet of epidemiology when I suggested that an association, however significant, between an independent variable (immunisation) and a dependent variable (disease) cannot be regarded as causal unless allowance is made for other variables known to influence susceptibility to the disease. Since the epidemiological data from Colindale discount all other variables, conclusions drawn from them are at best inferential. However, even without analysis of variables other than immunisation it is clear from both papers that the protection associated with immunisation is highly incomplete since $36 \%$ of all patients and $44 \%$ of patients aged 1-2 years described by Dr Miller and Mr Fletcher were fully immunised, as were $38 \%$ of the entire series presented by Dr Noah.

Dr N W Preston (14 February, p 396) seems to be in conflict with all of us. He despises notifications, so he presumably distrusts the Colindale data. But he agrees with their conclusions because he regards the new vaccine used by the Colindale workers as being effective because, in previous letters, he has said so. He considers that the decline in whooping cough is due to this new vaccine but does not say how he would explain the greater decline which occurred before it began to be used in 1968. He asks us to accept the new vaccine as being non-toxic because he says so and calls upon the world at large to provide evidence to the contrary. He asks me to provide evidence before criticising the Colindale data but does not hesitate to refute my evidence before it is published. He will find, incidentally, that I accept the desirability of bacteriological confirmation (who wouldn't ?), but he must surely know that in practice whooping cough is a disease in which an experienced doctor or parent is as likely to reach a correct diagnosis as a bacteriologist.

Mrs Rosemary Fox (21 February, p 458) draws attention to the need to investigate the possibility that the new vaccine may occasionally be neurotoxic. In my view she is correct in requesting a retrospective investigation, for it may be some years before the prospective survey authorised by the DHSS yields useful evidence.

GORDON T STEWART

Department of Community Medicine,

Department of Communit
University of Glasgow

\section{Primary gout affecting the sternoclavicular joint}

SIR,-The short report by Dr G R Sant and Mr E Dias (31 January, p 262) cannot be allowed to go unchallenged. The authors have committed two common errors in the diagnosis and management of this disease.

It is of course unjustifiable to diagnose gout of the sternoclavicular joint in an 18-year-old girl purely on the basis of raised plasma uric acid levels obtained at a time 